\title{
Serum High Sensitive C - reactive protein in Male Smokers of Bangladesh
}

\author{
Shamima Jahan', Qazi Shamima Akhter ${ }^{2}$
}

\begin{abstract}
Background: Smoking may cause systemic inflammation, and high level of serum high sensitive Creactive protein may be found in smoker as an indicator of inflammation. Objective: To assess the serum high sensitive C - reactive protein level in male smokers of Bangladesh. Methods: The present cross sectional study was carried out in the Department of Physiology, Dhaka Medical College, Dhaka between July 2013 and June 2014. Hundred apparently healthy male regular cigarette smokers aged 20 to 40 years who smokes at least 5 sticks of cigarette per day for the last 5 years were included as study group. They were further divided in to 5-10 years, 11-15 years, 16-20 years and 1-10 cigarette sticks, 1120 cigarette sticks, more than 20 cigarette sticks/day depending on the duration of smoking and also according to consumption of number of sticks/day respectively. Age matched 100 apparently healthy male nonsmokers were included for control. To assess their inflammatory status, serum hs-CRP level was estimated by particles enhanced immunonephelometry using BN Systems in the Department of Microbiology \& Immunology, Bangabandhu Sheikh Mujib Medical University (BSMMU), Dhaka. In addition, BMI and blood pressure were measured by standard method to observe their association with smoking. Results: The mean serum hs-CRP level was significantly higher in male smokers than that of non smokers which was progressively increased with duration of smoking and number of cigarette sticks consumed per day. Again, mean BMI was significantly lower and diastolic blood pressure was significantly higher in male smokers than those of non smokers. Conclusion: The result of this study can be concluded that serum hs-CRP level progressively increases with duration of smoking and number of cigarette sticks consumed per day in male smokers.
\end{abstract}

Keywords: Serum hs-CRP, BMI, Blood pressure, male smoker

J Bangladesh Soc Physiol. 2015, June; 10(1): 36-40 For Authors Affiliation, see end of text.

http://www.banglajol.info/index.php/JBSP

\section{Introduction}

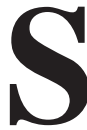

Smoking is the inhalation of the smoke of burned tobacco that may occur occasionally or habitually as a consequence of a physical addiction to nicotine ${ }^{1}$.A person, who smoked at least 100 cigarettes in his entire life is known as current smoker ${ }^{2}$.

More than 4000 compounds have been identified in tobacco smoke ${ }^{3}$. Among them, major

Received April 2011; Accepted November 2011 components are nicotine, tar, carbon monoxide and certain other poisonous substances like hydrogen cyanide, nitrogen oxide and ammonia etc ${ }^{4}$.

Nicotine is a natural alkaloid which is obtained from the dried leaves and stems of tobacco plants. It is considered as the main component of cigarette which causes addiction ${ }^{5}$. About 6 to 18 $\mathrm{mg}$ of nicotine is present per gram of cigarette. At the time of smoking, from each cigarette about 
$1.6 \mathrm{mg}$ of nicotine is delivered to air, which is very dangerous for passive smokers ${ }^{6}$.

Prevalence of smoker in the world is increasing day by day. According to WHO, current prevalence of smoker in the world is about $22.20 \%$ and in Bangladesh current prevalence of smoker is about $23 \%{ }^{7}$.

Smoking accelerates atherosclerosis in different arteries $^{8}$. It is well known that, active smoking causes micro vascular complications, acute myocardial infarction, stroke, a range of cancers and sudden death ${ }^{9}$. Passive smokers may also suffer from these diseases ${ }^{10}$.

Serum hs-CRP, the main acute phase protein, is a sensitive marker for systemic inflammation in humans. It is produced mainly by the liver and to some extent by the adipose tissue in response to proinflammatory cytokine induced by inflammatory stimuli. Among apparently healthy men and women, the currently recommended serum hs-CRP cut-off points are $<1.0 \mathrm{mg} / \mathrm{L}$ for low risk, $1-3 \mathrm{mg} / \mathrm{L}$ for average risk and $>3.0 \mathrm{mg} / \mathrm{L}$ for high risk of future $\mathrm{CVD}^{11}$. Cigarette smoking is a classical and a major risk factor for development of inflammatory condition which can be assessed by serum high sensitive Creactive protein (hs-CRP) level ${ }^{12}$.

Low grade inflammation indicated by the serum hs-CRP level, which may act as risk factor to develop future atherosclerosis ${ }^{13}$.

On the contrary some authors found no change of hs-CRP level in smokers ${ }^{14,15}$.

Several studies have done abroad to observe the association of hs-CRP level with smoking but the relationships are still debatable. However little is known regarding this topic in our country.

Therefore, this study was carried out to assess the serum hs-CRP level in Bangladeshi male smokers.

\section{Methods}

The present cross sectional study was carried out in the Department of Physiology, Dhaka
Medical College, Dhaka between July 2013 and June 2014. Protocol of this study was approved by Ethical Review Committee of Dhaka Medical College, Dhaka. For this study, hundred apparently healthy male cigarette smokers aged 20-40 years who smokes at least 5 sticks of cigarette per day for the last 5 years were included as study group. They were further divided in to 5-10 years, $11-15$ years, $16-20$ years and 1-10 cigarette sticks, 11-20 cigarette sticks, more than 20 cigarette sticks/day depending on the duration of smoking and also according to consumption of number of sticks/day respectively. For comparison, age matched another hundred apparently healthy male nonsmokers were included as controls. All of the subjects were selected by personal contact from different areas of Dhaka city by simple random sampling. After selection of the subjects, the nature, purpose and benefit and risks of the study were explained in details. They were encouraged for voluntary participation. They were also allowed to withdraw from the study whenever they like. Informed written consent was taken from the participants. Before taking blood, detailed family and medical history were taken and recorded in a prefixed questionnaire. To assess their inflammatory changes serum hs-CRP level was estimated by particles enhanced immunonephelometry using BN Systems ${ }^{16}$ in the Department of Microbiology \& Immunology, BSMMU, Dhaka. In addition, BMI and blood pressure were measured by standard method to observe their association with smoking. Moreover inflammatory changes of the smokers of this study were categorized by low ( $<1 \mathrm{mg} / \mathrm{L})$, moderate $(1-3 \mathrm{mg} / \mathrm{L})$ and high $(>3 \mathrm{mg} / \mathrm{L})$ risks according to their cutoff value ${ }^{17}$. For statistical analysis unpaired Student's 't' test was performed by using SPSS version 17.

\section{Results}

The baseline characteristics of non smokers and smokers are present in Table I. The mean value of BMI was significantly ( $\mathrm{p}<0.001$ ) lower and 
diastolic blood pressure was significantly (p < 0.001 ) higher in all smokers than those of non smokers.

In the present study, the mean serum hs-CRP level was significantly ( $p<0.001$ ) higher in smokers than that of non smokers (Figure 1). Moreover in this study, among the 100 study subjects, serum hs-CRP level was found $<1 \mathrm{mg} / \mathrm{L}$ in $3.0 \%, 1-3 \mathrm{mg} / \mathrm{L}$ in $15.0 \%$ and $>3 \mathrm{mg} / \mathrm{L}$ in $82.0 \%$ subjects (Figure-2). Again, serum hs-CRP level was gradually increased with duration of smoking and number of cigarette sticks per day (Table-II, III).

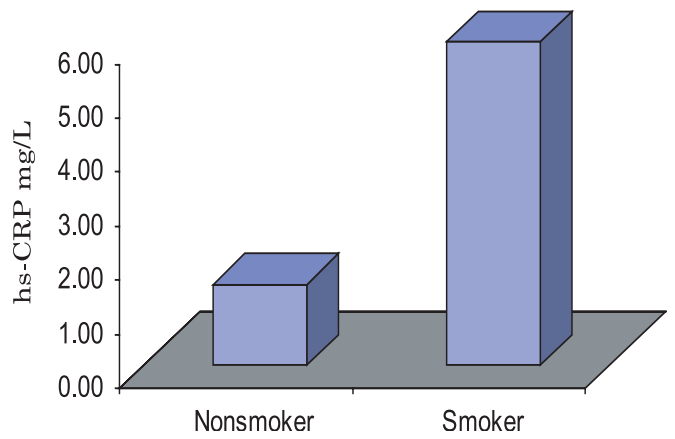

Figure 1: Mean Serum hs-CRP level in both groups $(n=200)$

$\mathrm{n}=$ total number of subjects
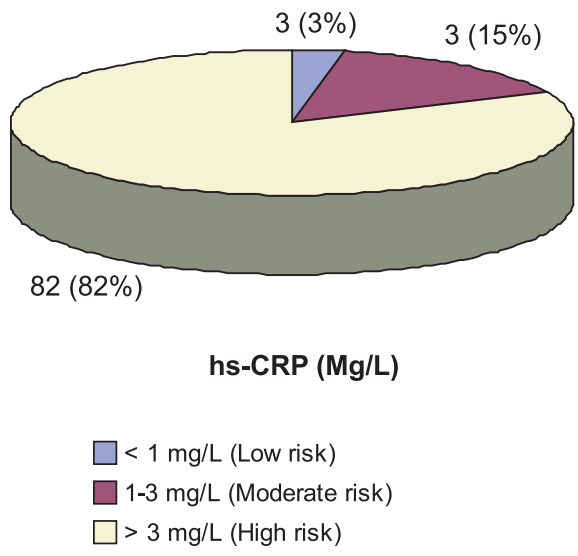

Figure 2: Frequency \% by serum hs-CRP level for risk stratification in smokers $(n=100)$ $\mathrm{n}=$ total number of subjects
Table I : Baseline characteristics in smokers and nonsmokers $(n=200)$

\begin{tabular}{lcc}
\hline Parameters & $\begin{array}{c}\text { Non smoker } \\
(\mathrm{n}=100)\end{array}$ & $\begin{array}{c}\text { Smoker } \\
(\mathrm{n}=100)\end{array}$ \\
\hline Age (years) & $34.96 \pm 4.74$ & $33.64 \pm 6.07$ \\
& $(21-40)$ & $(20-40)$ \\
BMI $\left(\mathrm{Kg} / \mathrm{m}^{2}\right)$ & $23.12 \pm 2.26$ & $19.18 \pm 3.367^{*}$ \\
& $(18.19-32.00)$ & $(12.90-33.50)$ \\
SBP (mm Hg) & $110.65 \pm 7.02$ & $110.85 \pm 9.536$ \\
& $(100-125)$ & $(90-170)$ \\
DBP (mm Hg) & $65.95 \pm 6.34$ & $69.55 \pm 8.11^{*}$ \\
& $(60-80)$ & $(60-85)$ \\
\hline
\end{tabular}

Results are expressed as Mean \pm SD. Figures in parentheses indicate range. Data are analyzed by unpaired t test. $\mathrm{SBP}=$ Systolic blood pressure $\mathrm{DBP}=$ Diastolic blood pressure, $\mathrm{BMI}=$ Body mass index.*p $<0.001$

Table II: Serum high sensitive C-reactive protein (hsCRP) level in smokers of different duration ( $\mathrm{n}=100)$

\begin{tabular}{lc}
\hline Duration (Year) & hs-CRP(mg/L) \\
\hline $5-10$ & $4.65 \pm 2.27$ \\
$(\mathrm{n}=35)$ & $(1-8.12)$ \\
$11-15$ & $5.84 \pm 2.19$ \\
$(\mathrm{n}=56)$ & $(1-10.0)$ \\
$16-20$ & $7.96 \pm 2.18$ \\
$(\mathrm{n}=6)$ & $(4-10.0)$ \\
\hline
\end{tabular}

Data were expressed as Mean \pm SD. Figures in parentheses indicate ranges.

$\mathrm{n}=$ total number of subjects

Table III: Serum high sensitive C-reactive protein (hs-CRP) level in smokers according to the number of cigarette sticks/day $(n=100)$

\begin{tabular}{lc}
\hline Number of cigarette & $\begin{array}{c}\text { hs-CRP(mg/L) } \\
\text { sticks/ day }\end{array}$ \\
\hline $1-10$ & $4.84 \pm 2.39$ \\
$(\mathrm{n}=37)$ & $(1-10.0)$ \\
$11-20$ & $6.01 \pm 2.28$ \\
$(\mathrm{n}=62)$ & $(1-10.0)$ \\
$>21$ & $7.00 \pm 0.00$ \\
$(\mathrm{n}=1)$ & $(7.0)$ \\
\hline
\end{tabular}

Data were expressed as Mean \pm SD. Figures in parentheses indicate ranges.

$\mathrm{n}=$ total number of subjects

J Bangladesh Soc Physiol. 2015, June; 10(1): 36-40 


\section{Discussion}

In the present study, the mean serum hs-CRP level was higher in smoker than that of non smokers. Moreover, a significant positive correlation of hs-CRP with the duration and number of cigarette sticks per day were also found in this group of population. Almost similar findings were reported by the various investigators from different countries ${ }^{18}$. Moreover, most of the smokers (82\%) of this study were at high risk, $15 \%$ were at moderate risk and remaining $3 \%$ were at low risk for the development of atherosclerosis. Almost similar observations were made by other researchers ${ }^{19}$.

Cigarette smoking is a classical and a major risk factor for development of inflammation which can be assessed by serum hs-CRP level. Inflammatory response produce increase number of polymorphonuclear neutrophil from the bone marrow, which secretes proinflammatory cytokine IL-1b, IL-6 and (TNF) - á. These cytokines bind to hepatocyte surface receptors and increase serum concentration of hs-CRP ${ }^{20,21}$. In atherosclerosis, the serum hs-CRP level indicates the low-grade inflammation in the vessel wall and greater cardiovascular risk in future 22 .

C-reactive protein increases low density lipoprotein uptake into macrophages then it inhibits endothelial nitric-oxide synthase in aortic endothelial cells and increases plasminogen activator inhibitor- 1 activity ${ }^{23}$, there by enhances atherosclerosis.

Nicotine, the major addictive component of tobacco, which reduces appetite and alters feeding patterns typically resulting in reduced body weight and thereby decrease BMI in smokers ${ }^{24}$. Again, nicotine raises blood pressure by constricting blood vessels. It stimulates the production of a hormone epinephrine from the adrenal gland. Epinephrine raises blood pressure by constricting blood vessels ${ }^{25}$.

In this study inflammatory changes were found in male smokers as evidenced by their measured
hs-CRP level. Again, in this study inflammatory changes were more pronounced in the subjects who are smoking for a long time and also in subjects taking more number of cigarette sticks per day. These statements can be supported by positive correlation of hs-CRP with the duration of smoking and number of cigarette sticks per day. Moreover, most of the smokers (82\%) of this study were at high risk for the development of atherosclerosis, as evidenced by their measured hs-CRP value, which is $>3.0 \mathrm{mg} / \mathrm{L}$. Again increased diastolic blood pressure in the smokers of this study indicates atherosclerotic changes in smokers.

\section{Conclusion}

From the results of this study, it can be concluded that serum hs-CRP level progressively increases with duration of smoking and number of cigarette sticks per day in male smokers.

\section{Authors Affiliations}

1. *Shamima Jahan, Assistant Professor, department of Physiology. Tairunnessa Memorial Medical College, Gazipur, Dhaka, Bangladesh. Email: urdoctor31@yahoo.com

2. Qazi Shamima Akhter, Professor, Department of Physiology, Dhaka Medical College, Dhaka, Bangladesh. Email: shamimaqazi @ yahoo.com

*For correspondence

\section{References}

1. Leone A, Landini L, Leone A. What is Tobacco Smoke? Socio cultural Dimensions of the Association with Cardiovascular Risk . Curr Pharm Des. 2010;16(23):2510-17.

2. Ryan H, Trosclair A and Gfroerer J. Adult Current Smoking: Differences in Definitions and Prevalence Estimates-NHIS and NSDUH, 2008.J Environ Public Health.2012:1-11.

3. Nnorom IC, Osibanjo O and Nnorom CG. Cadmium determination in cigarettes available in Nigeria. African J Biotech. 2005;4(10):1128-32.

4. Chalouhi N, Ali MS, Starke RM, Jabbour PM, Tjoumakaris SI, Gonzalez RH, et.al . Cigarette Smoke and Inflammation: Role in Cerebral Aneurysm Formation and Rupture. Mediators Inflamm. 2012:1-12. 
5. Benowitz NL. Nicotine Addiction. N Engl J Med. 2010;362:2295-303.

6. Zbancioc G, Drochioiu G, Mangalagiu. Nicotine and tobacco alkaloids: a GC-MS analysis. International J Criminal Investigation. 2012;2(4):251-57.

7. WHO. WHO report on the global tobacco epidemic. Warning about the dangers of tobacco. 2011. available from http://www.who.int/tobacco/ global_report/2011/en/index.html accessed in August 09, 2013

8. Venn A, Britton J. Exposure to Secondhand Smoke and Biomarkers of Cardiovascular Disease Risk in Never-Smoking Adults. Circulation. 2007;115: 99095.

9. Benowitz NL and Gourlay SG. Cardiovascular Toxicity of Nicotine: Implications for Nicotine Replacement Therapy. JACC. 1997;29:1422-31.

10. Schroeder SA. New Evidence That Cigarette Smoking Remains the Most Important Health Hazard. N Engl J Med. 2013;368:389-93.

11. Masood A, Jafar SS, Akram Z. Serunm high sensitivity C- reactive protein levels and the severity of coronary atherosclerosis assessed by angiographic gensini score. J Pak Med Assoc. 2011;61(4):325-27.

12. Ambrose JA, Barua RS. The Pathophysiology of Cigarette Smoking and Cardiovascular Disease. JACC. 2004;43:1731-37.

13. Jialal I, Devaraj S. The Value of the High-Sensitivity C- Reactive Protein Assay as a Risk Marker. Am J Clin Pathol. 2001;116:108-15.

14. Ulucay A, Demirbag R, Yilmaz R, Unlu D, Gur M, Selek S et al. The Relationship Between Plasma CReactive Protein Levels and Presence and Severity of Coronary Stenosis in Patients With Stable Angina. Angiology. 2008;58(6):657-62.
15. Miao D, Huang T, Ye P, Xiao W, Zhang Jand Wu H. Homocysteine not high sensitive $\mathrm{C}$ - reactive protein, associates with the intima-media thickness of carotid artery and arterial stiffness. Afr J Pharm Pharmacol. 2013;7(9):503-11.

16. Ridker PM. Circulation. 2003;107:363-369.

17. Mazurek K, Zmijewski P, Czajkowska A, Lutoslawska G. High sensitive $\mathrm{C}$ reactive protein (hs CRP) in young adults: Relation to aerobic capacity, physical activity and risk factors for cardiovascular diseases. Biol sport . 2011;28: 227-232.

18. Riordan MO. Cigarette smoking increases CRP, fibrinogen, and homocysteine levels. Medscape. 2003:1-7.

19. Roivainen $\mathrm{M}$, Viik-Kajander $\mathrm{M}$, Palosuo $\mathrm{T}$, Toivanen P, Leinonen M, Saikku Pet al. Infections, Inflammation, and the Risk of Coronary Heart Disease. Circulation.2000;101:252-257.

20. Tonstad S, Cowan JL. C-reactive protein as a predictor of disease in smokers and former smokers. Int J Clin Pract. 2009:1-13.

21. Thakur S, Gupta S, Parchwani H, Shah V and Yadav V. Hs-CRP - A Potential Marker for Coronary Heart Disease. Indian J Fundam Appl Life Sci. 2011; 1(1):2231-45

22. Madadi R, Haddadian K, Ghaderi E, Karim K. Diagnostic value of high sensitivity C-reactive protein in differentiating unstable angina from myocardial infarction. Chron Dis J. 2013;1(1): 7-12.

23. Black S, Kushner I and Samols D. C-reactive Protein. J Biol Chem.2004;279(47):48487-90.

24. Jo YA, Talmage DA and Role LW. Nicotinic Receptor-Mediated Effects on Appetite and Food Intake. J Neurobiol. 2002 ; 53(4): 618-632.

25. Ilgenli TF, Akpinar O, Acute effects of smoking on right ventricular function. Swiss med wkly 2007;137:91. 